\title{
Effect of Using Lower Linear Density Bobbin Thread on Seam Strength
} Vpliv manjše dolžinske mase čolnične niti na trdnost šiva

\author{
Short Scientific Article/Kratki znanstveni prispevek \\ Received/Prispelo 12-2018 • Accepted/Sprejeto 4-2019
}

\begin{abstract}
Needle thread loses significant strength when incorporated into the seam. The needle thread being weaker tends to fail under load which results in a catastrophic failure of the seam. The use of a lower linear density bobbin thread is suggested in order to balance out the loss in the needle thread, which can help improve the production efficiency without compromising the seam strength. In this paper, four combinations of needle/bobbin threads are used at various process parameters to study the impact of a lower linear density bobbin thread on the seam strength. The seam strength prediction in such an asymmetrical combination of the needle and bobbin thread is also a subject of exploration in this paper as previous research has only taken place in an ideal situation where the same needle and bobbin threads were used.
\end{abstract}

Keywords: seam strength, loop strength, thread strength loss, stitch density

\section{Izvleček}

Igelna nit izgubi precejšen del trdnosti, ko je vgrajena $v$ šiv. Pod vplivom obremenitve se bo igelna nit z nižjo trdnostjo prej pretrgala, kar lahko povzroči katastrofalen pretrg šiva. Pri uporabi čolnične nitiz manjšo dolžinsko maso bi bile uravnotežene poslabšane lastnosti igelne niti, kar bi pripomoglo k izboljšanju učinkovitosti proizvodnje, ne da bi se pri tem poslabšala trdnost šiva. Članek proučuje vpliv manjše dolžinske mase čolnične niti na trdost šiva pri uporabi štirih različnih kombinacij igelnih in čolničnih niti in pri različnih procesnih parametrih. Predmet te raziskave je tudi napovedovanje trdnosti šiva pri uporabi različnih kombinacij igelnih in čolničnih niti, saj so bile dosedanje raziskave izvedene pri idealnih pogojih, ko sta čolnična in igelna nit enaki.

Ključne besede: trdnost šiva, trdnost zanke, izguba trdnosti niti, gostota šiva

\section{Introduction}

The characteristic parameters of the seam are its strength, puckering, stiffness, appearance and efficiency [1]. According to many researchers [2], there are various factors affecting the seam quality, e.g. sewing thread, sewing condition etc. However, the sewing thread size is the most crucial factor for the apparel seam stability, as an improper use of the seam thread size affects directly the seam quality of apparel. A good sewing thread should give satisfactory sewing and seam performance. The sewing performance of threads is generally assessed by studying the

Corresponding author/Korespondenčni avtor:

Vinay Kumar Midha

E-mail: midhav@rediffmail.com dynamic tension and the strength reduction of the thread $[3,4]$. During the sewing, the needle thread is subjected to friction and tensile, bending, compressive, shear and surface stresses while passing through the machine elements and fabric assembly, leading to the loss in strength $[5,6]$. The extent of strength reduction is a function of the magnitude of stresses acting on the threads and their ability to withstand the degrading effect of stresses [7]. The reduction in thread strength is a consequence of changes in the mechanical properties of fibres, of dynamic loading and/or of the changes in the thread structure [8]. Various researchers have observed that the extent of

Tekstilec, 2019, 62(2), 148-154

DOI: 10.14502/Tekstilec2019.62.148-154 
these stresses and friction is higher on the needle thread as compared to the bobbin thread. A typical cotton sewing thread may show a $20-30 \%$ loss in the needle thread as compared to the $8-10 \%$ loss in the bobbin thread depending upon various process parameters [5]. Due to different losses in the needle and bobbin thread during the sewing, the needle thread becomes weaker and may fail under these stresses, resulting in seam failure. Further, the imbalance in the strength of the needle thread and bobbin thread is expected to affect the seam strength as well. Therefore, in this paper, cotton and polyester threads with lower linear density were used as the bobbin thread, whereas cotton and polyester threads with higher linear density were used as the needle thread. It is expected that the needle thread loses more strength during the sewing; therefore, the needle thread strength after the sewing should match the bobbin thread strength after the sewing. The use of a lower linear density thread gives higher length of the thread in the bobbin, which consequently reduces the frequency of bobbin changes. Moreover, the seam strength prediction can also be improved by understanding the role of these stresses during the sewing process.

\section{Materials and methods}

Mercerized spun cotton thread of linear density 30 tex, 40 tex and 60 tex, and spun polyester thread of linear density 27 tex, 40 tex and 60 tex were used to prepare seams on $250 \mathrm{~g} / \mathrm{m}^{2}$ and $350 \mathrm{~g} / \mathrm{m}^{2}$ denim fabric with right hand twill (100\% cotton) at different stitch densities, i.e. 8,10 and 12 stitches $/ 25.4 \mathrm{~mm}$. The threads are characterized with the number of plies, twist direction, and twist and tensile properties as shown in Table 1.

The physical properties of fabrics are shown in Table 2. The breaking strength of the fabric was tested warp-wise as per ASTM D 5035(Strip test) on a Tinius Olson universal testing machine. The transverse seam strength was tested warp-wise in line with ASTM D1683.

The sewing thread tensile test was conducted on a universal testing machine (Tinius Oleson) at the gauge length of $250 \mathrm{~mm}$ according to the ASTM standard D2256 using the test speed which corresponds to $20 \mathrm{~s}$ breaking time. The sewing threads were also tested for loop strength in accordance with the ASTM standard D2256 at the $250 \mathrm{~mm}$ gauge length. The loop strength testing was done for different combinations of loops formed using

Table 1: Physical properties of sewing threads

\begin{tabular}{|c|c|c|c|c|c|c|c|}
\hline Thread type & $\begin{array}{c}\text { Linear } \\
\text { density } \\
{[\text { tex }]}\end{array}$ & $\begin{array}{c}\text { Number } \\
\text { of plies }\end{array}$ & $\begin{array}{c}\text { Twist } \\
\text { direction: } \\
\text { single/ply }\end{array}$ & $\begin{array}{c}\text { Twist } \\
{[1 / \mathrm{m}]}\end{array}$ & $\begin{array}{c}\text { Tenacity } \\
{[\mathrm{cN} / \text { tex }]}\end{array}$ & $\begin{array}{c}\text { Breaking } \\
\text { elongation } \\
{[\%]}\end{array}$ & $\begin{array}{c}\text { Initial } \\
\text { modulus } \\
{[\mathrm{cN} / \mathrm{tex}]}\end{array}$ \\
\hline \multirow{3}{*}{ Spun cotton } & 30 & 3 & $\mathrm{~S} / \mathrm{Z}$ & 840 & 25.7 & 5.15 & 586 \\
\cline { 2 - 8 } & 40 & 3 & $\mathrm{~S} / \mathrm{Z}$ & 707 & 33.2 & 7.18 & 546 \\
\cline { 2 - 8 } & 60 & 3 & $\mathrm{~S} / \mathrm{Z}$ & 597 & 31.4 & 7.95 & 366 \\
\hline \multirow{3}{*}{ Spun polyester } & 27 & 2 & $\mathrm{~S} / \mathrm{Z}$ & 689 & 20.9 & 14.22 & 205 \\
\cline { 2 - 8 } & 40 & 2 & $\mathrm{~S} / \mathrm{Z}$ & 711 & 36.9 & 14.68 & 154 \\
\cline { 2 - 8 } & 60 & 2 & $\mathrm{~S} / \mathrm{Z}$ & 590 & 34.9 & 17.01 & 132 \\
\hline
\end{tabular}

Table 2: Physical properties of fabrics

\begin{tabular}{|c|c|c|c|c|c|c|c|}
\hline $\begin{array}{c}\text { Fabric } \\
\text { density } \\
{\left[\mathrm{g} / \mathrm{m}^{2}\right]}\end{array}$ & $\begin{array}{c}\text { Weave } \\
\text { pattern }\end{array}$ & $\begin{array}{c}\text { Fabric } \\
\text { thickness } \\
{[\mathrm{mm}]}\end{array}$ & Ends/cm & Picks/cm & $\begin{array}{c}\text { Warp } \\
\text { linear } \\
\text { density } \\
{[\text { tex }]}\end{array}$ & $\begin{array}{c}\text { Weft } \\
\text { linear } \\
\text { density } \\
{[\text { tex }]}\end{array}$ & $\begin{array}{c}\text { Fabric } \\
\text { strength } \\
{[\mathrm{N}]}\end{array}$ \\
\hline 250 & $\left.2 / 1 \mathrm{RHT}^{\mathrm{a}}\right)$ & 0.67 & 25.98 & 18.11 & 49.16 & $49.16^{\mathrm{b})}$ & 328.55 \\
\hline 350 & $\left.2 / 1 \mathrm{RHT}^{\mathrm{a}}\right)$ & 0.82 & 27.16 & 18.11 & 65.55 & $65.55^{\mathrm{b})}$ & 395.29 \\
\hline
\end{tabular}

a) Right hand twill

b) Open-end yarn 
threads of different linear densities as shown in Table 3. The statistical t-test at $95 \%$ confidence level was performed for loop strength. A Juki industrial lockstitch sewing machine was run at the speed of 3000 stitches/min for the seam preparation using different linear densities of threads in the needle and bobbin as shown in Table 3. The seam strength testing was carried out as per ASTM standard 1683. The fabrics were stitched along the warp direction, which is the most common for garment seams. Moreover, the statistical t-test at $95 \%$ confidence level was conducted for seam strength (Table 3 ).

The thread profile in the seam resembles a loop and tends to have a similar failure mechanism; hence, the seam strength was calculated by multiplying the loop strength of threads and the number of loops that contribute to the seam strength. The seam strength prediction was done for all the thread combinations using equation 1 [5]. It was then compared with the experimental seam strength (Figures $1 \mathrm{a}$ and $1 \mathrm{~b})$.

Estimated seam strength $(\mathrm{N})=$ Stitch density (stitches $/ 25 \mathrm{~mm}) \times$ Loop strength $(\mathrm{N})$

\section{Results and discussion}

\subsection{Effect of linear density of threads on thread loop strength}

Table 3 shows the seam strength values for two different types of fabrics using different needle and bobbin thread combinations sewn at different stitch densities. It was observed that the seam strength at the 30 tex/30 tex: needle thread/bobbin thread (cotton) combination was lower than at other combinations of threads in the set, i.e. 30 tex/40 tex: needle thread/bobbin thread (cotton), 40 tex /30 tex: needle thread/bobbin thread (cotton) thread. The 40 tex/40 tex: needle thread/bobbin thread (cotton) combination showed significantly higher seam strength due to stronger threads showing higher loop strength. In the 30 tex/40 tex: needle thread/ bobbin thread (cotton) combination or 40 tex/30 tex: needle thread/bobbin thread (cotton) combination, the higher seam strength is attributed to the higher loop strength of the combination. It was observed that the loop strength of the 30 tex/30 tex: needle thread/bobbin thread (cotton) combination was $1354 \mathrm{cN}$ and that of $40 \mathrm{tex} / 40$ tex: needle thread/bobbin thread (cotton) $2298 \mathrm{cN}$, whereas the loop strength of the 30 tex/40 tex: needle thread/ bobbin thread (cotton) combination was $1452 \mathrm{cN}$. Using a thread with higher linear density in combination with a thread with lower linear density increased the loop strength of the thread marginally, which was statistically significant at $95 \%$ confidence level (Table 3). During the loop strength testing, the stress concentration was on the intersection point of the loops, which leads to the failure of loops from the point of stress concentration $[9,10]$.

\subsection{Effect of linear density of threads on seam strength}

The seam strength of the seam assembly made of threads with different linear densities in the needle and bobbin were tested as well, and the results are shown in Table 3. It was observed that the seam strength at the 40 tex/30 tex: needle thread/bobbin thread (cotton) combination was higher than at the30 tex/40 tex: needle thread/bobbin thread (cotton) combination for both fabrics. The same trend was observed at other combinations, i.e. at 60 tex/40 tex threads, although the trend was statistically significant in only few cases. This is due to the seam and loop strengths being dependent on the strength of the weaker thread, i.e. 30 tex. The loop failure is the reason for the seam failure in an ideal condition where all the loops are evenly stressed [11]. During the sewing process, the needle thread is exposed to higher stresses during the passage through the machine, as compared to bobbin thread. The needle thread gets more damage as compared to the bobbin thread. According to literature, the cotton needle thread loses $25-30 \%$ of strength, whereas the cotton bobbin thread loses only $8-10 \%$ of strength during the sewing process. When a 30 tex thread was used as the needle thread and 40 tex as the bobbin thread, the 30 tex needle thread lost more strength and the seam strength hence depended on the 30 tex thread, which further weakened. On the other hand, when a 30 tex thread was used as the bobbin thread and 40 tex thread was used as the needle thread, the 40 tex needle thread became weaker and lost more strength as compared to the 30 tex bobbin thread, and at the time of loading of loops during the seam strength testing, both threads had similar strengths and therefore showed higher strength as compared to the 30 tex/40 tex: needle thread/bobbin thread 
combination. The same trends were observed for the combinations of 60 tex/40 tex: needle thread/bobbin thread (cotton), 40 tex/27 tex: needle thread/bobbin thread (polyester) and 60 tex/40 tex: needle thread/ bobbin thread (polyester).

\subsection{Comparing experimental seam strength with estimated seam strength using loop strength of different linear densities of threads}

The seam strength values were calculated with equation 1, using the loop strength values for different

Table 3: Seam strength at different combinations of needle and bobbin thread

\begin{tabular}{|c|c|c|c|c|c|c|c|c|c|c|}
\hline \multirow{4}{*}{ Set } & \multirow{4}{*}{$\begin{array}{l}\text { Needle- } \\
\text { bobbin } \\
\text { thread } \\
\text { combina- } \\
\text { tion }\end{array}$} & \multirow{4}{*}{$\begin{array}{c}\text { Needle } \\
\text { thread } \\
\text { [tex]/ } \\
\text { bobbin } \\
\text { thread } \\
\text { [tex] }\end{array}$} & \multirow{4}{*}{$\begin{array}{c}\text { Thread } \\
\text { type }\end{array}$} & \multirow{4}{*}{$\begin{array}{l}\text { Loop } \\
\text { strength } \\
\text { [cN] }\end{array}$} & \multicolumn{6}{|c|}{ Seam strength $[\mathrm{N}] / \mathrm{CV}[\%]$} \\
\hline & & & & & \multirow{2}{*}{\multicolumn{3}{|c|}{$\begin{array}{c}\text { Denim fabric - } \\
250 \mathrm{~g} / \mathrm{m}^{2} \\
\text { Stitch density } \\
\text { [stitches } / 25.4 \mathrm{~mm} \text { ] }\end{array}$}} & \multirow{2}{*}{\multicolumn{3}{|c|}{$\begin{array}{c}\begin{array}{c}\text { Denim fabric - } \\
350 \mathrm{~g} / \mathrm{m}^{2}\end{array} \\
\text { Stitch density } \\
\text { [stitches } / 25.4 \mathrm{~mm} \text { ] }\end{array}$}} \\
\hline & & & & & & & & & & \\
\hline & & & & & 12 & 10 & 8 & 12 & 10 & 8 \\
\hline \multirow[t]{5}{*}{1} & 1 & $30 / 30$ & Cotton & 1354 & $134 /$ & $118 /$ & $106 /$ & $153 /$ & $119 /$ & $100 /$ \\
\hline & & & & & 1.93 & 5.05 & 5.34 & 11.65 & 2.50 & 7.90 \\
\hline & 2 & $30 / 40$ & Cotton & $1452^{\mathrm{a})}$ & $\begin{array}{c}167^{\mathrm{a}) /} \\
4.95\end{array}$ & $\begin{array}{l}132 / \\
8.09\end{array}$ & $\begin{array}{l}111 / \\
5.10\end{array}$ & $\begin{array}{l}162 / \\
851\end{array}$ & $\begin{array}{c}127 / \\
10.54\end{array}$ & $\begin{array}{l}111 / \\
3.97\end{array}$ \\
\hline & 3 & $40 / 30$ & Cotton & 1452 & $\begin{array}{c}178^{c) /} \\
4.32\end{array}$ & $\begin{array}{c}\left.146^{c}\right) / \\
6.45\end{array}$ & $\begin{array}{l}97 \mathrm{~b}) / \\
5.93\end{array}$ & $\begin{array}{l}164 / \\
683\end{array}$ & $\begin{array}{c}\left.138^{c}\right) / \\
685\end{array}$ & $\begin{array}{l}114 / \\
287 \mathrm{~s}\end{array}$ \\
\hline & 4 & $40 / 40$ & Cotton & $2298^{\mathrm{d})}$ & $\begin{array}{c}205^{\mathrm{d}) /} \\
9.64\end{array}$ & $\begin{array}{c}189^{\mathrm{d}) /} \\
6.82\end{array}$ & $\begin{array}{c}143^{\mathrm{d}) /} \\
6.03\end{array}$ & $\begin{array}{c}212^{\mathrm{d}) /} \\
7.38\end{array}$ & $\begin{array}{c}188^{\mathrm{d}) /} \\
8.46\end{array}$ & $\begin{array}{c}145^{\mathrm{d}) /} \\
7.22\end{array}$ \\
\hline \multirow[t]{7}{*}{2} & 1 & $40 / 40$ & Cotton & 2298 & $205 /$ & $189 /$ & $143 /$ & $212 /$ & $188 /$ & $145 /$ \\
\hline & & & & & 9.64 & 6.82 & 6.03 & 7.38 & 8.46 & 7.22 \\
\hline & 2 & $40 / 60$ & Cotton & $2438^{\text {a) }}$ & $211 /$ & $190 /$ & $150 /$ & $208 /$ & $190 /$ & $137 /$ \\
\hline & & & & & 4.82 & 4.26 & 1.97 & 3.81 & 6.99 & 6.88 \\
\hline & 3 & $60 / 40$ & Cotton & 2438 & $222 /$ & 198/ & $163^{\mathrm{c}) /}$ & $236^{\mathrm{b}, \mathrm{c})} /$ & $208 /$ & $165^{\mathrm{b}) /}$ \\
\hline & & & & & 6.82 & 6.03 & 7.38 & 8.46 & 7.22 & \\
\hline & 4 & $60 / 60$ & Cotton & $\left.3237^{d}\right)$ & $\begin{array}{c}277^{\mathrm{d}) /} \\
2.66\end{array}$ & $\begin{array}{c}267^{\mathrm{d}) /} \\
3.24\end{array}$ & $\begin{array}{c}250^{\mathrm{d}) /} \\
2.03\end{array}$ & $\begin{array}{c}342^{\mathrm{d}) /} \\
2.72\end{array}$ & $\begin{array}{c}271^{\mathrm{d}) /} \\
1.49\end{array}$ & $\begin{array}{c}227^{\mathrm{d}) /} \\
3.55\end{array}$ \\
\hline \multirow[t]{6}{*}{3} & 1 & $27 / 27$ & Polyester & 1083 & $114 /$ & $100 /$ & $85 /$ & $127 /$ & $85 /$ & $82 /$ \\
\hline & & & & & 11.55 & 8.18 & 5.86 & 10.89 & 8.72 & 9.64 \\
\hline & 2 & $27 / 40$ & Polyester & $1290^{\mathrm{a})}$ & $139^{\mathrm{a}) /}$ & $121^{\mathrm{a})} /$ & $99^{\text {a) } /}$ & $150^{\mathrm{a}) /}$ & $137^{\mathrm{a}) /}$ & 97a)/ \\
\hline & & & & & 9.45 & 5.85 & 2.37 & 6.50 & 7.04 & 6.97 \\
\hline & 3 & $40 / 27$ & Polyester & 1290 & $\begin{array}{c}158^{\mathrm{c})} / \\
5.95\end{array}$ & $\begin{array}{c}141^{\mathrm{b}, \mathrm{c})} / \\
8.47\end{array}$ & $\begin{array}{l}104^{c} / \\
962\end{array}$ & $\begin{array}{l}170^{c} / / \\
1552\end{array}$ & $\begin{array}{c}\left.130^{c}\right) / \\
866\end{array}$ & $\begin{array}{c}103^{c} / \\
403\end{array}$ \\
\hline & 4 & $40 / 40$ & Polyester & $2209^{d)}$ & $\begin{array}{c}264^{\mathrm{d}) /} \\
3.47\end{array}$ & $\begin{array}{c}216^{\mathrm{d}) /} \\
6.43\end{array}$ & $\begin{array}{c}173^{\mathrm{d} / /} \\
5.33\end{array}$ & $\begin{array}{c}227^{\mathrm{d}) /} \\
2.40\end{array}$ & $\begin{array}{c}212^{\mathrm{d}) /} \\
6.99\end{array}$ & $\begin{array}{l}177^{\mathrm{d}) /} \\
4.88 \mathrm{~s}\end{array}$ \\
\hline \multirow[t]{6}{*}{4} & 1 & $40 / 40$ & Polyester & 2209 & $264 /$ & $216 /$ & $173 /$ & $227 /$ & $212 /$ & $176 /$ \\
\hline & & & & & 3.47 & 6.43 & 5.33 & 2.40 & 6.99 & 4.88 \\
\hline & 2 & $40 / 60$ & Polyester & $2533^{\text {a) }}$ & $269 /$ & $227 /$ & $177 /$ & $262^{\mathrm{a}) /}$ & $230^{\mathrm{a}) /}$ & $186 /$ \\
\hline & & & & & 0.82 & 4.14 & 4.87 & 2.23 & 6.72 & 3.02 \\
\hline & 3 & $60 / 40$ & Polyester & 2533 & $\begin{array}{c}248^{\mathrm{b}) /} \\
3.94\end{array}$ & $\begin{array}{c}241^{c /} / \\
4.57\end{array}$ & $\begin{array}{c}159^{\mathrm{b}) /} \\
6.77\end{array}$ & $\begin{array}{c}289^{\mathrm{b}, \mathrm{c})} / \\
7.24\end{array}$ & $\begin{array}{c}231^{\mathrm{c})} / \\
2.96\end{array}$ & $\begin{array}{l}184 / \\
4.74\end{array}$ \\
\hline & 4 & $60 / 60$ & Polyester & $3224^{\mathrm{d})}$ & $\begin{array}{c}294^{\mathrm{d}) /} \\
5.53\end{array}$ & $\begin{array}{c}288^{\mathrm{d}) /} \\
4.48\end{array}$ & $\begin{array}{c}257^{\mathrm{d}) /} \\
3.73\end{array}$ & $\begin{array}{c}326^{\mathrm{d}) /} \\
2.50\end{array}$ & $\begin{array}{c}275^{\mathrm{d}) /} \\
3.32\end{array}$ & $\begin{array}{c}258^{\mathrm{d}) /} \\
4.26\end{array}$ \\
\hline
\end{tabular}

a) Significant w.r.t. combination 1 at same process parameters at $95 \%$ confidence level, b) Significant w.r.t. combination 2 at same process parameters at $95 \%$ confidence level, c) Significant w.r.t. combination 1 at same process parameters at $95 \%$ confidence level, d) Significant w.r.t. combinations 1, 2, 3 at 95\% confidence level, Where w.r.t. stands for "with respect to" 


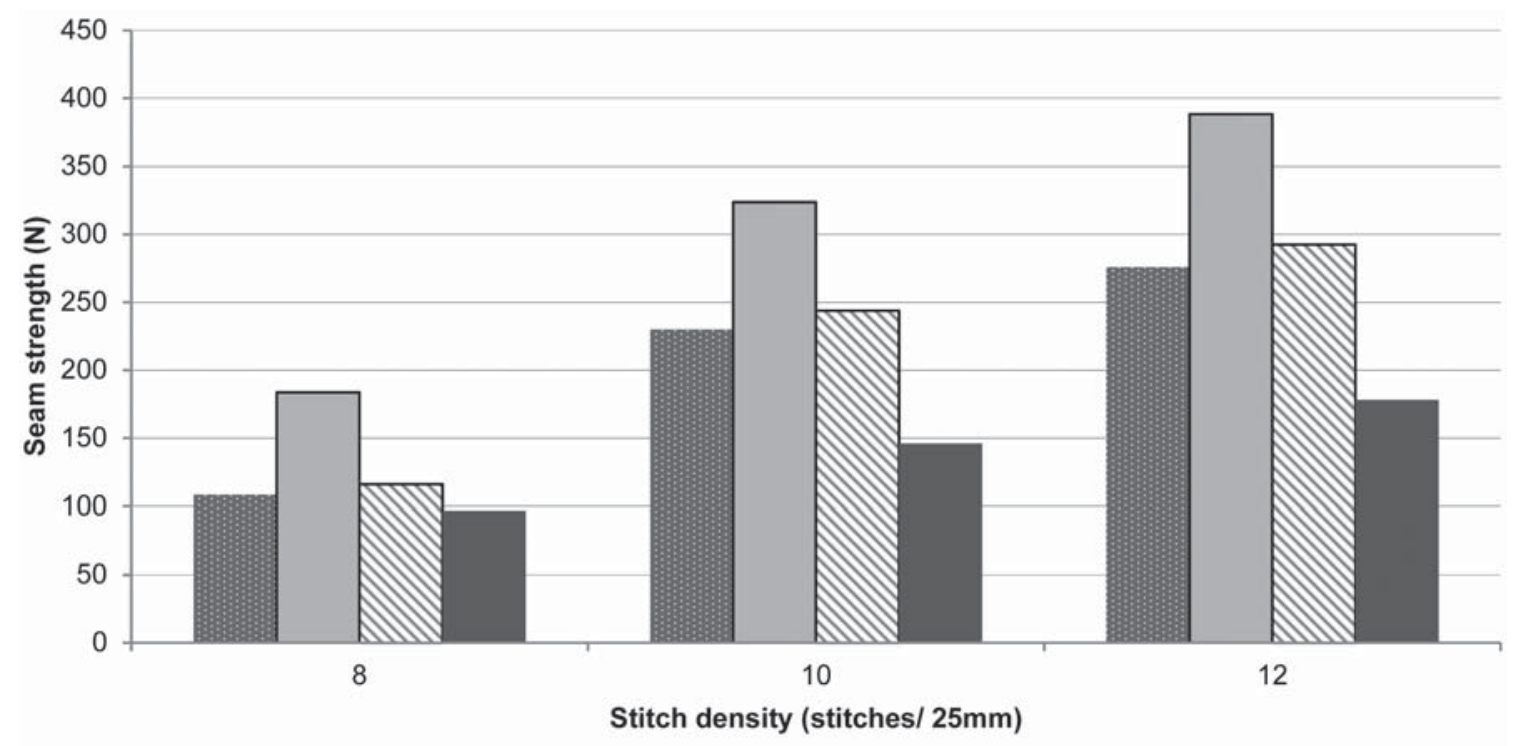

Predicted seam strength using loop strength of 30 tex mercerized cotton thread

$\square$ Predicted seam strength using loop strength of 40 tex mercerized cotton thread

$\checkmark$ Predicted seam strength using loop strength of 40 tex/30 tex mercerized cotton thread combination

- Actual seam strength

Figure 1: Experimental seam strength vs predicted seam strength for 40 tex/30 tex (needle/bobbin) spun cotton thread combination on $250 \mathrm{~g} / \mathrm{m}^{2}$ denim fabric

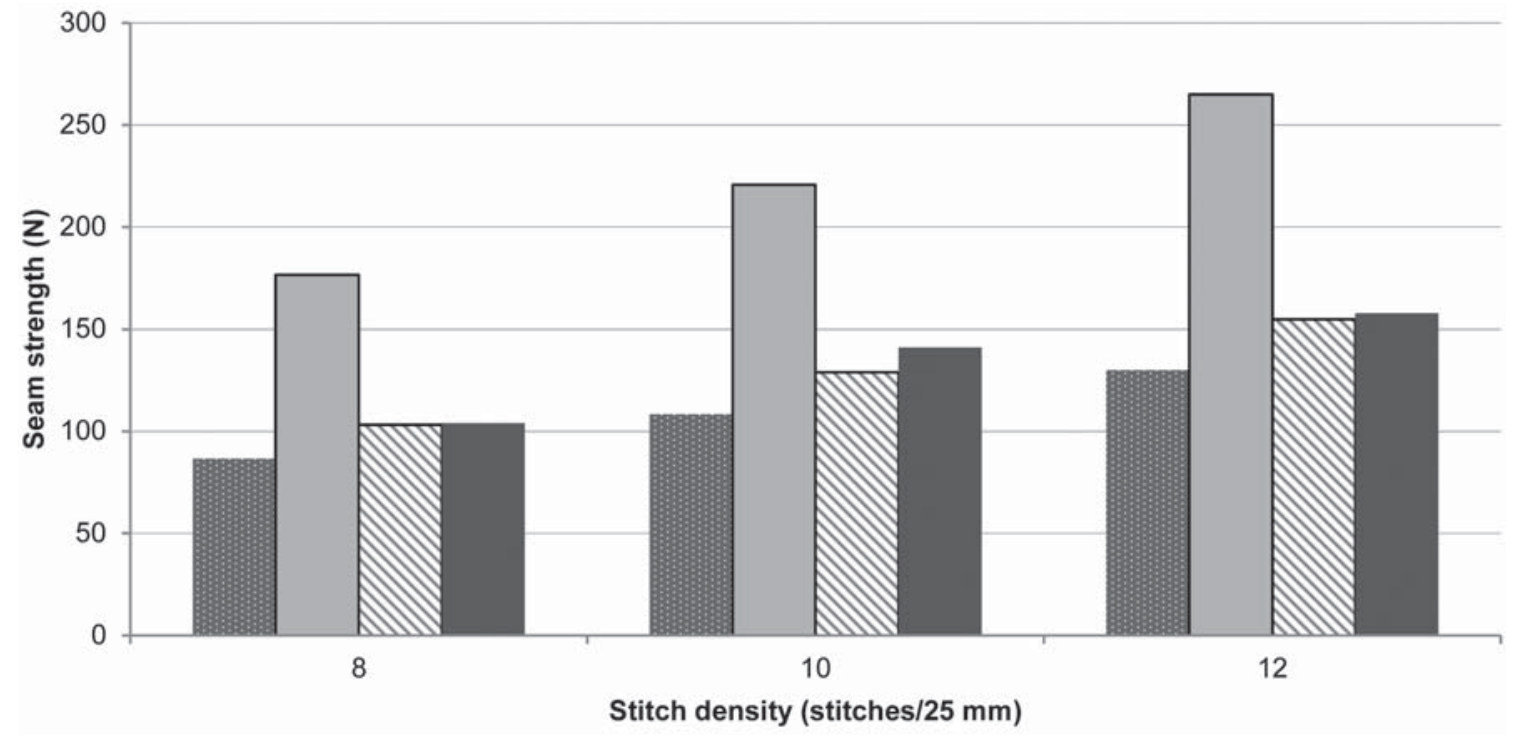

: Predicted seam strength using loop strength of 27 tex spun polyester

$\square$ Predicted seam strength using loop strength of 40 tex spun polyester

vPredicted seam strength using loop strength of 40 tex spun polyester/27 tex spun polyester combination

actual seam strength

Figure 2: Experimental seam strength vs predicted seam strength for 40 tex/27 tex (needle/bobbin) spun polyester thread combination on $250 \mathrm{~g} / \mathrm{m}^{2}$ denim fabric 
combinations of needle/bobbin threads, i.e. using loop strength of 30 tex cotton, using loop strength of 40 tex cotton thread and using loop strength of 40 tex/30 tex threads taken together. Similarly, the seam strength values for polyester threads were estimated as well. The calculated seam strength values were compared with the experimental seam strength values to find out the loop strength combination that gives a closer estimate of the seam strength. Figure 1 demonstrates that there is a significant difference between the experimental and predicted seam strength for the 40 tex/30 tex: needle/bobbin (cotton) thread combination at the stitch densities of 10 and 12 , while the difference is lower at 8 stitches $/ 25 \mathrm{~mm}$. This may be a combined effect of increased thread strength loss and fabric damage due to higher stitch density. The seam strength estimation was closer to the experimental values when the loop strength of the thread with lower linear density, i.e. 30 tex cotton thread, or loop strength of 40 tex/30 tex: needle thread/bobbin thread was taken. Moreover, the same trend was observed at the 60 tex/40 tex: needle/bobbin cotton thread combination. At the 40 tex/27 tex: needle/bobbin spun polyester thread combination, the experimental seam strength was very close to the estimated seam strength calculated using the loop strength of 40 tex/27 tex: needle/bobbin spun polyester thread (Figure 2). The same trend was observed at the 60 tex/40 tex: needle/bobbin spun polyester thread combination also at different stitch densities, which results from the thread damage during the sewing being very low in the case of polyester threads. Consequently, the loop strength is directly reflected into the seam strength at different stitch densities at the polyester thread.

\section{Conclusion}

The seam strength increases with the use of a higher linear density (higher strength) thread in the needle and bobbin, which is due to the increased average loop strength compared to lower linear density threads in the needle and bobbin. When different threads are used in the needle and bobbin, the seam assembly where a higher linear density thread is used in the needle and a lower linear density thread is used in the bobbin shows higher seam strength compared to the seam assembly where a lower linear density thread is used in the needle and a higher linear density thread in the bobbin. Since the needle thread is exposed to various stresses during the passage through the machine and the bobbin thread experiences lower stresses, the needle thread gets more damaged as compared to the bobbin thread. The loss in the tensile properties of the needle thread is reflected in the seam strength values of a fabric. The use of a lower linear density thread in the bobbin significantly reduces the seam strength as compared to higher linear density threads in both the needle and bobbin; however, the predicted seam strength values are substantially higher than the actual seam strength values. Since polyester threads undergo less damage during the sewing process, the actual seam strength values are closer to the predicted values when a lower linear density thread is used as the bobbin thread.

\section{References}

1. DOBILAITE, Vaida, JUCIENE, Milda. The influence of mechanical properties of sewing threads on seam pucker. International Journal of Clothing Science and Technology, 2006, 18(5), 335-345.

doi: 10.1108/ 09556220610685276.

2. MERIC, B., DURMAZ, A. Effect of thread structure and lubrication ratio on seam properties. Indian Journal of Fibre and Textile Research, 2005, 30(3), 273-277.

3. MIDHA, Vinay Kumar, KOTHARI, V. K., CHATTOPADHYAY, R., MUKHOPADHYAY, Arunaganshu. Effect of high-speed sewing on the tensile properties of sewing threads at different stages of sewing. International Journal of Clothing Science and Technology, 2009, 21(4), 217-238, doi: 10.1108/09556220910959981.

4. MIDHA, Vinay Kumar, MUKHOPADHYAY, Arunangshu, CHATTOPADHYAY, R., KOTHARI, V. K. Studies on the changes in tensile properties of sewing thread at different sewing stages. Textile Research Journal, 2009, 79(13), 1155-1167, doi: 10.1177/0040517508101456.

5. MIDHA, Vinay Kumar, MUKHOPADHYAY, Arunangshu, KAUR, Ramanpreet. An approach to seam strength prediction using residual thread strength. Research Journal of Textile and 
Apparel, 2011, 15(3), 75-85, doi: 10.1108/RJTA15-03-2011-B009.

6. FERREIRA, F. B. N., HARLOCK, S. C., GROSBERG, P. A study of thread tensions on a lockstitch sewing machine (Part I). International Journal of Clothing Science and Technology 1994, 6(1), 14-19, doi: 10.1108/09556229410054468.

7. SUNDARESAN, G., HARI, P. K., SALHOTRA, K. R. Strength reduction in sewing threads during high speed sewing in an industrial lockstitch machine: Part I - mechanism of thread strength reduction. International Journal of Clothing Science and Technology, 1997, 9(5), 334-345, doi: 10.1108/09556229710185460.

8. RUDOLF, Andreja, GERŠAK, Jelka. Study of the relationship between deformation of the thread and built-in- fibers. International Journal of Clothing Science and Technology, 2001, 13(3/4,), 289-300, doi: 10.1108/EUM0000000005783.

9. MIDHA, Vinay Kumar, GUPTA, Ashish K, MUKHOPADHYAY, Arunaganshu. Effect of gauge length on loop strength of sewing threads. The Journal of the Textile Institute, 2018, 110(3), 445-450, doi: 10.1080/00405000.2018.1489339.

10. RENGASWAMI, R. S., WESLEY, Samuel. Tensile behavior of sewing threads under simple- tensile, loop and knot tests. Journal of Textile and Apparel, Technology and Management, 2011, 7(2), 1-21.

11. BRAIN, D. H. The prediction of strengths of lockstitch seams in woven fabrics. Journal of Textile Institute, 1970, 61(10), 493-505, doi; 10.1080/00405007008630015. 